\title{
Al'Adâlah \\ PENGARUH PEMBACAAN AL-QURAN BIN NAGHAM (TILAWAH) PADA KETENANGAN JIWA SANTRI PONPES LSQ AR-RAHMAH BANTUL
}

\author{
Andy Rosyidin \\ Ilmu al-Qur'an dan Tafsir UIN Sunan Kalijaga Yogyakarta \\ Andyrosyidin123@gmail.com
}

\begin{abstract}
The Qur'an is interesting to study because it has secrets that many people don't know about without being aware of. One of them is about the element of ashShifa, namely the Koran as a medicine / antidote as stipulated in the Koran Surah Al-Isra ': 82. In some interpretations the purpose of the drug or the antidote is not limited to disturbances in the body but dzohir / physical also felt the presence of these miracles. Various methods can be done by someone to get the miracle of al-Qur'an as ash-Shifa, one of them is by reciting the Qur'an method. Namely reading the Koran by using tones and charts (tausyih) which have been commonly used in Musabaqah Tilawatil Qur'an (MTQ) starting from the baby and its derivation to the level of the Jiharkah song. In processing this article the authors used a descriptive-qualitative method that is by describing the evidence that the Qur'an read by the recitation method has an influence on the psychology (peace of mind) of readers and listeners. Then use interview techniques as a data collection. As for the scope of this study, the author focuses on the students at the Islamic Boarding School LSQ ar-Rahmah Bantul Yogyakarta.
\end{abstract}

Keywords: Tilawah al-Qur'an, LSQ Ar-Rahmah, ash-Syifa and Peace of Soul

\section{Pendahuluan}

Al-Quran adalah kitab suci umat Islam yang selalu menjadi kitab pedoman dalam kehidupan sehari-hari, di samping itu, al-Quran memiliki fungsi yang berbagai macam, salah satunya adalah sebagai asy-Syifa yakni Obat, hal ini didasari oleh sebuah ayat "Dan Kami turunkan dari Al-Qur'an suatu yang menjadi penawar dan rabmat bagi orang-orang yang beriman dan Al Quran itu tidaklah menambah kepada orang-orang yang zalim selain kerugian" (QS. Al-Isra': 82).

Menurut Imam Thantawi ketika menafsirkan ayat tersebut, beliau mengatakan bahwa maksud obat pada ayat tersebut adalah obat untuk penyakit fisik dan jiwa. Itu berarti al-Quran memiliki keistimewaan dan implikasi, tatkala seseorang membaca maupun ketika mendengarkan, hal ini sebenarnya menjadi menarik lagi ketika al-Quran 
dibaca secara mendalam dan dihayati, ada beberapa cara atau metode seseorang untuk mendapatkan penghayatan dalam membaca al-Quran, salah satunya dengan membaca al-Quran dengan bertilawah, yakni melantunkan al-Quran dengan melagukan ayat atau membaca sesuai dengan irama yang memiliki beberapa tingkatan atau tangga lagunya. Inilah yang dikatakan bahwa al-Quran sebagai kitab yang performatif.

Mengenai perintah membaca al-Quran secara performatif, sebenarnya telah diatur dalam hadis dari al-Barra bin Azib Radhiyallahu 'anhu, Rasulullah Shallallahu 'alaihi wa sallam berpesan,

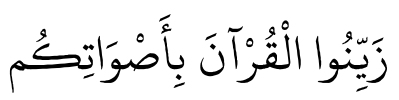

Artinya: "Hiasilah al-Quran dengan suara kalian". (HR. Ahmad 18994, Nasai 1024, dan disbabihkan Syuaib al-Amauth). Bahkan dalam satu hadis pun mengatakan bahwa "Siapa yang tidak memperindah suaranya ketika membaca al-Quran, maka ia bukan dari golongan kami." (HR. Abu Daud 1469, Ahmad 1512 dan dishabibkan Syuaib al-Amauth).

Sesuai dengan keterangan di atas tentu ada rahasia di balik anjuran tersebut. Terlebih jika dikaitkan dengan maksud al-Quran sebelumnya yakni sebagai syifa (obat). Oleh karena itu peneliti tertarik untuk menggali lebih dalam lagi mengenai pengaruh alQuran ketika dibaca dengan nagham (tilawah) terhadap psikologi seseorang dalam hal ini subjek atau informannya adalah para santri khususnya di Pondok Pesantren LSQ arRahmah Bantul Yogyakarta asuhan Prof. Dr. KH Abdul Mustaqim S. Ag M. Ag.

\section{Kerangka Teori}

Pada penelitian ini penulis menggunakan teori fungsionalisme, teori ini terkenal pada akhir 1930-an, dan mengandung pandangan makroskopis terhadap masyarakat. Walaupun pendekatan ini bersumber pada sosiolog-sosiolog Eropa seperti Max Webber, Emile Durkheim, Vilfredo Pareto, dan beberapa antropolog sosial Inggris, namun yang pertama mengemukakan rumusan sistematis mengenai teori ini adalah Talcot Parsons, dari Harvard. ${ }^{1}$

Teori fungsionalisme disebut juga teori Fungsionalisme Struktural. Teori ini kemudian dikembangkan oleh para mahasiswa Parson, dan para murid mahasiswa tersebut, terutama di Amerika. Pendekatan ini didasarkan pada dua asumsi dasar yaitu :

1. Masyarakat terbentuk atas substruktur-substruktur yang dalam fungsi-fungsi mereka masing-masing, saling bergantung, sehingga perubahan-perubahan yang terjadi dalam fungsi satu sub-struktur dengan sendirinya akan tercermin pada perubahan-perubahan yang terjadi dalam struktur-struktur lainnya pula. Karena itu, tugas analisis sosiologis adalah menyelidiki mengapa yang satu mempengaruhi yang lain, dan sampai sejauh mana.

2. Setiap struktur berfungsi sebagai penopang aktivitas-aktivitas atau

${ }^{1}$ M. Anam, "Implementasi Sosiologi Dilakukan Di Amaliah Sholawat Wahidiyah Syekh KH. Abdoel Madjid Ma'roef”, dalam Skripsi (UIN Sunan Ampel Surabaya, 2016), hlm 20 
substruktur-substruktur lainnya dalam suatu sistem sosial. Contoh-contoh substruktur ini dalam masyarakat adalah keluarga, agama, pendidikan, dan pranatapranata mapan lainnya.

Dalam agama Islam, Islam hadir sebagai agama yang berfungsi dan bertujuan membenarkan akidah masyarakat yang buta akan kehidupan spiritual yang sesuai dengan kultur masyarakat sekitar. Dalam perspektif teori sosiologi, sebuah penelitian yang melibatkan kehidupan beragama (pengalaman keagamaan) dapat didekati dengan teori fungsional. ${ }^{2}$

Seperti yang pernyataan Durkheim, bahwa ia tertarik kepada unsur-unsur solidaritas dalam masyarakat. Durkheim mencari prinsip yang mempertalikan anggota di masyarakat. Ia menyatakan bahwa agama harus mempunyai fungsi, agama bukan illusi, tetapi merupakan fakta sosial yang dapat diidentifikasi dan mempunyai kepentingan sosial, bagi Durkheim agama memainkan peranan yang fungsional, karena agama adalah pondasi tatanan sosial. Dalam karyanya yang berjudul Elementary Forms of the Religious Life, Emile Durkheim menunjukan bukti-bukti antropologis guna memperkuat argumennya, bahwa pengalaman religius menjadi pondasi tatanan sosial.

\section{Hasil Penelitian}

\section{Pengaruh Tilawah al-Quran bin Nagham Pada Ketenangan Jiwa Santri LSQ Ar-Rahmah: Analisis Teori Fungsionalis}

Al-Quran diturunkan sebagai Asy-Syifa (obat) bagi umat Nabi Muhammad Saw. di mana, menurut Imam Thantawi ketika menafsirkan kata asy-Syifa tersebut, beliau mengatakan bahwa maksud obat tersebut adalah obat untuk penyakit fisik dan jiwa. Ini berarti al-Quran memiliki pengaruh yang sangat besar bagi siapa saja yang membacanya.

Muhammad Quraish Sihab menjelaskan bahwa dalam literature keagamaan dan sejarah dapat kita buktikan mengenai adanya pengaruh al-Qur'an tersebut, yaitu melalui kisah dari Sahabt Umar Bin Khattab dan al-Walid al-Mughirah yang bergetar jiwanya ketika dibacakan al-Quran. Beberapa ulama menjadikan kasus tersebut sebagai bukti bahwa siapapun yang membaca dan mendengarkan bacaan al-Quran akan memperoleh pengaruh positif bagi psikologis, salah satunya mendapat ketengan dalam jiwanya. ${ }^{3}$

Al-Quran sebagai mukjizat dapat memberikan ketenangan tersendiri bagi jiwa yang dilanda kesedihan dan penyakit-penyakit lainnya. Al-Lahim menjelaskan bahwa kondisi jiwa dan hati seseorang yang hatinya selalu disibukkan dengan al-Quran: ${ }^{4}$

1. 'Tidak merasa jemu dan bosan apabila dekat dengan al-Qur'an dengan intesnsitas hlm.3.

2 O'dea Thomas F, Sosiologi Agama; Suatu Pengenalan Awal (Jakarta: Rajawali, 1990),

3 Titin Setyawati,"Hubungan Antara Tilawah Al Qur'an Dengan Kesiapan Belajar Siswa Kelas IX di Mts Muhammadiyah Wangon Tahun Pelajaran 2016/2017"dalam Tesis (Universitas Muhammadiyah Purwokerto: Fakultas Agama Islam, 2017), hlm. 28

4 Titin Setyawati,“Hubungan Antara Tilawah Al Qur'an Dengan Kesiapan Belajar Siswa Kelas IX di Mts Muhammadiyah Wangon Tahun Pelajaran 2016/2017”,... hlm. 29-30. 
Al-‘adalah, Volume 22 Nomor 1, April 2019

yang panjang.

2. Rindu akan al-Qur'an, terutama ketika rentan aktu yang lama ketika berpisah dengannya.

3. Mentaati al-Qur'an, baik itu perintah maupun larangannya

4. Merasa tenang, karena al-Qur'an dijadikan pedoman hidup dalam kehidupan sehari-hari, selalu merujuk kepadanya dan selalu bersandar kepadanya ketika mendapat persoalan hidup yang besar maupun kecil.

Allah sendiri menerangkan kepada kita hubungan erat antara bacaan ayatayat AlQur'an dengan jiwa dan emosi seorang yang mendengarkannya. Membaca Al-Qur'an dapat membuat hati gemetar sebagaimana firman Allah: "Sesungguhnya orang-orang yang beriman ialah mereka yang bila disebut nama Allah gemetarlah hati mereka, dan apabila dibacakan ayat-ayat Nya bertambahlah iman mereka (karenanya), dan hanya kepada Tubanlah mereka bertawakkal". (QS. Al-Anfal: 2)

Kemudian Tilawatil Qur'an juga dapat menenangkan pikiran orang yang sedang berdzikir dengan Al-Qur'an: "(yaitu) orang-orang yang beriman dan hati mereka manjadi tenteram dengan mengingat Allah. Ingatlah, hanya dengan mengingat Allah-lah hati menjadi tenteram." (QS. Ar-Ra'd: 28)

Kondisi kejiwaan tergantung pada suasana dan energi yang dibawa oleh Al-Qur'an. Dr Ahmad Al-Qadhi, direktur utama Islamic Medicine Institute for Education and Research melalui penelitiannya yang panjang dan serius di salah satu klinik di Florida, Amerika Serikat, berhasil membuktikan bahwa hanya dengan mendengarkan bacaan ayat-ayat Al-Qur'an, seorang muslim baik yang mengerti bahasa Arab maupun tidak, dapat merasakan perubahan psikologi yang sangat besar. ${ }^{5}$

Hal itu pula yang dirasakan oleh sebagian santri LSQ Ar-Rahmah yang penulis jadikan subyek atau responden dari penelitian. Rata-rata santri mengakui bahwa ketika mereka membaca maupun mendengarkan bacaan al-Qur'an yang dibaca dengan tilawah (bin Nagham), mereka merasakan dampak yang signifikan yakni mendapat ketenangan Jiwa, dan itu dirasakan baik yang bagi yang membaca maupun mendengarkan.

Dapat dipertajam lagi menggunakan teori fungsionalisme dari Emile Durkheim yang mengatakan bahwa ada pengaruh dari agama terhadap perilaku sosial masayarakat, dalam hal ini bahwa al-Qur'an memiliki sebuah mukjizat yang sangat besar yakni dapat mempengaruhi psikis atau psikologi seseorang yang membaca maupun mendengar.

\section{Deskripsi dan Analisis Data}

Profil Ponpes LSQ Ar-Rahmah Bantul ${ }^{6}$

Gagasan mendirikan pesantren bermula dari keinginan pendiri, bapak Dr. H.

\footnotetext{
${ }^{5}$ Nur Faizin Muhith, Manusia Mengeluh Al-Qur'an Menjawab, (Surakarta: Al-Qudwah Publishing, 2014), hlm.22.

${ }^{6}$ Muhammad Wahyudi, "LSQ Ar-Rahmah", dalam http://1sq-arrahmah.com/?p=1 diakses pada 24 Desember 2018
} 
Andy Rosyidin, Pengaruh Pembacaan Al-Qur'an...

Abdul Mustaqim yang mendambakan munculnya generasi muda-mudi Islam yang religious, kreatif, inovatif dan memiliki visi keumatan berbasis pada nilai-nilai Islam yang rahmatan lil a'lamin.

Pada mulanya, pesantren tersebut hanya berupa dua kamar gubug yang terbuat dari bambu untuk menampung dua santri (baca: mahasiswa), korban gempa yang terjadi pada tahun 2006. Meskipun ketika itu tidak mempunyai kamar, mereka ingin belajar agama, sembari tetap kuliah di perguruan tinggi di Yogyakarta. Kemudian, seiring berjalannya waktu ada beberapa santri dan mahasiswa ikut mengaji, baik sekedar santri "kalong" maupun santri mukim. Jumlah para santri mahasiswa ketika tahun 2007-2008 kurang lebih 15 sampai 18 orang, yang biasa ikut ngaji dan diskusi tentang tafsir dan ilmu tafsir setiap malam Ahad.

Kemudian pada tahun 2012 PP LSQ Ar-Rahmah dipercaya untuk ikut mengawal dan mendidik para santri PBSB (Program Beasiswa Santri Berprestasi) dari Prodi Ilmu Al-Qur'an dan Tafsir (IAT) Fakultas Ushuluddin dan Pemikiran Islam (FUSPI) UIN Sunan Kalijaga dengan jumlah 21 santri, dan juga 3 santri dari luar PBSB. Dan kemudian pada tahun 2015 santri PBSB di PP LSQ Ar-Rohmah bertambah 12 santri, sehingga jumlah total santri menjadi 46 baik dari PBSB maupun non PBSB . Jika ditambah santri non mukim (santri kalong) 3 orang, maka jumlah total 49 santri.

Berangkat dari kenyataan selama ini dari para mahasiswa di Yogyakarta, mereka di samping ingin kuliah di Perguruan Tinggi Negeri seperti UIN, UGM dan UNY, maupun di Perguruan Tinggi Swasta, seperti STIQ an-Nur, dan UMY, rupanya juga ingin nyantri di sebuah Pesantren. Maka Bapak Dr. H. Abdul Mustaqim, M.Ag dengan didukung oleh keluarga, para kolega, dan masyarakat di sekitar Perumahan Puri Tamanan Indah Grojogan, dengan mengucapkan bismillahh bertekad mendirikan Pesantren LSQ (Lingkar Studi al-Qur'an) Ar-Rohmah atau yang dalam bahasa Arab dapat diterjemahkan sebagai al-Ma'had al-Islami "al-Halaqah li Dirâsah al-Qur'an" ArRohmah.

Secara struktural, Pondok Pesantren Mahasiswa Lingkar Studi al-Qur'an (LSQ) Ar-Rohmah tersebut berada di bawah naungan YAYASAN IRSAD (Institut for Religious Studies and Democracy) dengan Akta Notaris Drs. M. Yusuf, S.H., Dipl. Eng., No. 05/17 Juli 2002, didirikan pada tanggal 4 Desember 2006.

Pemberian nama pesantren LSQ (Lingkar Studi al-Qur'an) tersebut tidak lepas dari model kajian yang awalnya berbentuk melingkar, ketika belum banyak diikuti santri, sehingga komunikasi Kyai/Ustad menjadi lebih efektif. Sementara itu, nama ArRohmah, terambil dari firman Allah surat al-Anbiya' 107, bahwa diutusnya Nabi Saw dengan membawa al-Qur'an tidak lain sebagai rahmah, yakni menebar nilai-nilai kasih sayang.

Dengan mengkhususkan pada kajian al-Qur'an, diharapkan, pesantren tersebut mendapat barakah dari Allah SWT melalui kajian al-Qur'an, baik melalui qiraa'atan (bacaan), fahman (pemahaman), tahfizhan (hapalan) mapun ‘amalan (pengamalan) nilai-nilai ajaran al-qur'an yang rahmatan lil alamin dalam kehidupan sehari-hari. 
Al-'adalah, Volume 22 Nomor 1, April 2019

Kehadiran pesantren LSQ Ar-Rohmah secara khusus memang diharapkan menjadi kawah condro dimuko bagi para mahasiswa dan santri yang tinggal di pesantren dan maupun para pemuda dan anak-anak di sekitar pesantren.

Deskripsi Wawancara

Pada sesi wawancara, penulis melibatkan 10 orang santri Pondok Pesantren LSQ ar-Rahmah, yang dibagi menjadi dua model Informan wawancara yakni; pertama, wawancara ditujukan kepada santri yang mempunyai kemampuan dalam melantunkan al-Quran dengan tilawah (Qori), dan kedua, wawancara kepada santri yang mendengar ketika al-Quran tersebut dilantunkan dengan tilwah. Untuk yang pertama yakni Qori penulis batasi kepada 5 oang santri; Ahmad Dziya'ul Haq, Abdi Nur Muhammad, Hanapi Nasution, Habib Arpaja (Santri Kalong) dan juga saudara Muaz. Sedangkan yang "Pendengar" ada 5 santri juga; Febrian Candra, Abdul Halim, Faruq Hakiki, Fikru Jayyid dan Abdul Mu'in.

Pada wawancara yang pertama yakni kepada para "Qori”, penulis mengajukan beberapa pertanyaan, yang utama adalah mengenai dampak ketika al-Quran yang dinaghamkan kepada psikologi mereka, kemudian mengenai tingkatan lagu favorit ketika melantunkan al-Quran tersebut dan terakhir adalah mengenai waktu favorit membaca al-Qurang dengan tilawah. Dari wawancara tersebut penulis mencoba membagi tanggapan mereka kedalam beberapa pola;

a. Bagaimana pendapat para qori ketika melantunkan al-Quran dengan Tilawah? (dari aspek psikologi)

Secara umum, dari tanggapan mereka, penulis tidak menemukan perbedaan yang mencolok, karena semua informan memiliki jawaban yang sama "Ketika membaca alQuran dengan tilawah hati akan mersa tenang, adem, dan juga tentram", karena katakata tersebut memiliki arti yang sepadan dalam Kamus Bahasa Indonesia, jadi penulis hanya mengkhususkan kedalam satu pola. Tetapi perbedaan signifikan dapat terlihat ketika mereka memaparkan alasan-alasannya, meskipun ada yang nyaris sama. Oleh karena itu, dari 5 informan penulis bagi kedalam dua pola: pertama, yang mengatakan mendapat ketenangan karena dapat menghayati dan mentadabburi (Muaz, Hanapi, Habib, Yaya) dan yang kedua: Tenang, karena membacanya dengan irama yang lambat (Abdi)

b. Apakah lagu favorit anda ketika melantukan al-Quran dengan tilawah?

Dari tanggapan informan penulis membaginya kedalam dua pola, pertama ada yang menyukai lagu bayati karena pembawaannya yang luwes dan kreasi nadanya lebih santai (Yaya), pola kedua yang menyukai nada atau irama nahawand yang secara garis besar alasannya sama yakni karena iramanya yang mendayu-dayu, iramanya halus dan mudah ditirukan (Muaz, Hanapi, dan Abdi) dan ketiga menyukai dua lagu Nahwand dan Rast (Habib)

c. Kapan waktu favorit membaca al-Quran dengan tilawah?

Dari 5 informan yang diwawancarai penulis membagi kedalam tiga pola; (1) ketika sedih; Yaya, (2) sendirian: Muaz, (3) Bosan Murattal: Habib (4) kapan saja: Abdi dan 
Andy Rosyidin, Pengaruh Pembacaan Al-Qur'an...

Hanapi. Berbagai alasan yang penulis dapatkan, "Ketika merasakan sedih" (yaya), alasannya karena memang al-Quran ketika dibaca biasa saja tidak ada impactnya berbeda dengan tilawah yang pembawaanya tenang jadi pada saat itu hati menjadi kebawa (baper), kemudian yang menjawab "ketika sendirian" (Muaz) alasan kedua informan hampir sama yakni al-Quran itu ibarat teman ketika kita baca apalagi dengan tilawah, selanjutnya informan yang menjawab "Ketika Bosan Murattal" (Habib) karena tilawah lebih menarik, kemudian yang menjawab "kapan saja" (abdi dan Hanapi) mereka beralasan bahwa karena hobi bisa dilakukan kapan saja dan di mana saja.

Kemudian pada sesi wawancara kedua yang informannya adalah "pendengar tilawah"para santri yakni ada 5 orang: Candra, Faruq, Fikru, Mu’in dan Halim. Mereka dijadikan sebagai informan karena sering mendengar tilawah baik secara langsung dari qori atau melalui media sosial seperi youtube dan lain sebagainya ada juga yang tidak terlalu menyukai tilawah. Adapun pertanyaan-pertanyaan yang penulis ajukan hampir sama dengan informan pada sesei wawancara yang pertama yakni mengenai dampak ketika mendengarkan bacaan al-Quran dengan nagham (tilawah), apakah lagu favorit ketika mendengarkan tilawah dan kapan waktu favorit mendengarkan tilawah.

Pada pertanyaan yang pertama, dari kelima nara sumber atau informan, dapat dipetakan kedalam dua pola, yang pertama Nyaman, Tenang, dan adem, Kemudian pola kedua "biasa saja" (Halim), perbedaannya berbeda ketika penulis menanykan perihal alasanny, untuk jawaban yang pertama bahwa dampak al-Quran yang dibaca tilawah tergantung kepada suara atau irama yang dibawakan oleh para qori (candra, faruq, fikru , Mu'in) ada berbagai alasan para informan, salah satunya misalnya saudara fikru ia mengatakan bahwa ia sangat senang atau terbawa ketika si qori membawakannya juga membawakan dengan tenang apalagi sesuai dengan tahsin dan tajwidnya, begitupun alasan dari informan-informan lainnya. Berbeda dengan saudara halim yang menurutnya, dampak dari tilwah ketia ia dengarkan biasa saja karena ia menganggap bahwa sama saja ketika al-Quran dibaca dengan biasa dan dengan tilawah.

Kemudian untuk pertanyakan kedua, mengenai lagu favorit ketika mendengarkan tilwah baik secara langsung maupun melalui media sosial Namun, secara umum para informan menjawab bahwa mereka selama ini hanya mendengarkan saja, tidak tahu sama sekali mengenai macam-macam nagham atau irama dalam tilawah tersebut, semisal saudara Halim, ia mengatakan bahwa ketika mendengarkan tilawah baik ketika ada seminar dan lain sebagainya ia hanya mendengarkan saja. Jadi pada pertanyaan kedua ini penulis hanya mendapatkan satu pola dari kelima informan tersebut.

Dan pertanyaan terakhir mengenai waktu favorit mendengar tilawah, secara umum tanggapan kelima informan terlihat berbeda dan penulis memabagi kedalam dua pola yakni ada yang menjawab ketika bosan (Candra, Faruq dan Mu'in), ketika sebelum tidur (Fikru) dan karena terpaksa (Halim). Dari alasan para informan penulis dapati berbagai perbedaan, misal dari pola pertama yakni yang mendengarkan ketika bosan atau banyak fikiran, saudara Mu'in mengatakan bahwa ketika bosan ia mendengarkan tilawah karena dengan mendengarkan tilawah kita bisa menghayati dan mentadabburi, 
kemudian untuk pola yang kedua, ketika sebelum tidur, saudara fikru mengatakan bahwa hal tersebut sudah menjadi kebiasannya sejak lama, dan untuk pola yang terakhir yakni terpaksa, informan yang menjawab terpaksa yakni saudara halim, dalam artian ketika ia mendengarkan bukan karena inisiatifnya melainkan karena tergantung kepada keadaan semisal ketika mengikuti acara-acara besar semisal seminar, kulaih umum dan lain sebagainya.

Dari beberapa wawancara di atas penulis menyimpulkan bahwa dampak dari pembacaan al-Quran dengan tilawah terhadap psikologi para santri baik yang qori maupun yang mendengarkan sangatlah beragam, namun secara garis besar baik dari informan yang pertama (qori) dan juga yang kedua (pendengar), yakni merasakan ketenangan dan kenyamanan. Terlepas dari itu tidak dinafikan bahwa tilawah juga tidak berdampak kepada psikologi seseorang semisal pada informan yang mendengarkan, hanya seorang yang menganggap bahwa hal tersebut adalah biasa saja. Hal tersebut disebabkan karena beberapa faktor, salah satunya karena tidak tahu makna ayat yang dibaca (tidak bisa menghayati), atau karena hanya sebatas mendengarkan saja sehingga terkesan terpaksa sehingga menganggapnya biasa saja tidak ada dampaknya.

\section{Kesimpulan}

Al-Quran yang sejatinya adalah kitab hidayah bagi manusia memiliki beberapa keutamaan, salah satunya adalah sebagai asy-Syifa yakni obat, termasuk makna obat di sini tidak terbatas pada penyakit jiwa/bathin melainkan fisik/dzohir pun juga. Untuk mendapatkan keistimewaan dari pengaruh al-Qur'an sebagai asy-Syifa dapat di dapat melalui beberapa metode salah satunya dengan metode pembacaan al-Qur'an dengan lagu (tilawah bin nagham) yakni membaca al-Qur'an sesuai dengan nada atau tangga lagu yang telah masyhur diperkenalkan oleh para Qari'. Di samping itu, kita sebagai umat Islam juga diperintah untuk membaca al-Qur'an dengan suara Indah. Karena ada tentunya ada rahasia dibalik perintah tersebut. Yakni mendapatkan ketenangan jiwa.

Hal tersebut dapat dibuktikan berdasar penelitian yang penulis lakukan di Pondok Pesantren LSQ Ar-Rahmah Bantul, dapat dianalisis dari beberapa pertanyaan yang penulis ajukan ke beberapa informan, sehingga mendapatkan sebuah fakta, bahwa dengan metode tilawah bin nagham tersebut mampu menggetarkan jiwa para santri, baik yang membaca maupun yang mendengarkan. Salah satu faktornya adalah karena mereka menghayati al-Qur'an yang dibaca bin Nagham tersebut. Oleh karena itu, bisa diakui bahwa al-Qur'an jika lebih dihayati dan lebih di selami maka pelakunya akan merasakan keuntungan dan keutamaan yang mulia yakni, mendapat ketenangan jiwa, menghilangkan persoalan hati dan sebagainya.

\section{Daftar Pustaka}

Aini, Indah Ro'fatul. “Hubungan Antara Pembiasaan Tilawah Al-Quran Dengan Kecerdasan Spiritual Siswa Di MAN 4 Bantul Yogyakarta", dalam skripsi 
Jurusan Pendidikan Agama Islam Fakultas Ilmu Tarbiyah Dan Keguruan UIN Sunan Kalijaga Yogyakarta. 2017.

Akbar, Abul Haris. Musikalitas al-Qur'an.tp. 2009

Anam, M. "Implementasi Sosiologi Dilakukan Di Amaliah Sholawat Wahidiyah Syekh KH. Abdoel Madjid Ma'roef”, dalam Skripsi UIN Sunan Ampel Surabaya. 2016.

Busroh. "Metode Pembelajaran Seni Tilawah Qur'an Di LPTQ Kota Pontianak", dalam artikel IAIN Pontianak: Procedings Book ICGC'17. 2017.

Daradjat, Zakiyah. Islam Untuk Disiplin Ilmu Kedokteran Dan Kesehatan 1. Jakarta: Direktorat Jenderal Kelembagaan Agama Islam. .2002.

Kesehatan Mental. Jakarta: Gunung Agung. 1982.

F, O'dea Thomas. Sosiologi Agama; Suatu Pengenalan Awal. Jakarta: Rajawali. 1990

Hadi, Sutrisno. Metodologi Research II. Yogayakarta: Fak. Psikologi UGM. 1993

Muhith, Nur Faizin. Manusia Mengeluh Al-Qur'an Menjawab. Surakarta: Al-Qudwah Publishing. 2014.

Mujid, Abdul \& Jusuf Mudzakkir. Nuansa-Nuansa Psikologi Islam. Jakarta: Raja Grafindo Persada. 2001.

Nelson, Kristina. The Art of Reciting the Qur'an. USA: University of Texas Press. 1985

Palmquist, Stephen. Fondasi Psikologi Perkembangan.Yogyakarta, Pustaka Pelajar. 2005.

Rasmussen,Anne. Women: The Recited Quran and Islamic Music in Indonesia. University of California Press. 2010

Rifa'ah, Siti. "Pengaruh Motivasi Membaca Al-Qur'an Terhadap Ketenangan Jiwa Santriwati Pondok Pesantren Putri Al-Hikmah Tugurejo Tugu Semarang", dalam Skripsi. Fakultas Ilmu Tarbiyah Dan Keguruan Institut Agama Islam Negeri Walisongo Semarang. 2013.

Satori, Djam'an. Metodologi Penelitian Kualitatif. Bandung: Alfabeta.2010

Setyawati,Titin. "Hubungan Antara Tilawah Al Qur'an Dengan Kesiapan Belajar Siswa Kelas IX di Mts Muhammadiyah Wangon Tahun Pelajaran 2016/2017"dalam Tesis. Universitas Muhammadiyah Purwokerto: Fakultas Agama Islam. 2017.

Tim Penyusun Kamus Pusat Pembinaan dan Pengembangan Bahasa Indonesia. Jakarta: Balai Pustaka. 1993.

Wahyudi, Muhammad. "LSQ Ar-Rahmah", dalam http://lsqarrahmah.com/?p=1.2018

Zahro, A. "Makna Ketenangan Jiwa Pada Lansia Setelah Mengamalkan Ajaran Tarekat Qadiriyyah Wa Naqsyabandiyah (Studi Kasus Jama'ah Di Desa Kesambi Bandung Tulungagung)", dalam Skripsi. IAIN Tulung Agung. 2015 